\title{
Experimentenwet: carte blanche verdient nadere overweging
}

\author{
Mr.P. Ingels $e^{*}$
}

\section{Inleiding}

De rechtspraak gaat experimenteren! Straks kan de regering ${ }^{1}$ bij algemene maatregel van bestuur (AMvB) bijkans alle bepalingen van de eerste drie boeken van het Wetboek van Burgerlijke Rechtsvordering, een deel van de Wet RO en nog een drietal wetten ten behoeve van experimenten vervangen door andere regels. Dat is niet niks. Een Experimentenwet rechtspleging die dit mogelijk maakt, ligt ter consultatie voor. ${ }^{2}$ Moet dit ons alarmeren? Is zo'n experimentenwet nodig? Kan niet nu al veel en zo ja, waarom gebeurt dat niet? Ik zal concluderen dat de wet bepaald nadere reflectie behoeft, maar ook dat experimenteren nuttig is en dat dat goed zonder dit wetsvoorstel kan, mits men bereid is daarin te investeren. $\mathrm{W}_{\mathrm{ij}}$ nemen eerst het voorstel onder de loep.

\section{Het consultatievoorstel}

Het voorstel wil de rechtspraak de mogelijkheid bieden om - met inachtneming van de fundamentele beginselen van procesrecht en binnen de grenzen van verdragen en EUregelgeving - te experimenteren met innovatieve civielrechtelijke procedures. Aldus kunnen verbeteringen 'met het oog op de behoefte van rechtzoekende burgers en bedrijven aan meer eenvoud, snelheid, flexibiliteit en effectiviteit bij gerechtelijke procedures' worden getest. ${ }^{3} \mathrm{Bij} \mathrm{AMvB}$ zal bij wijze van experiment kunnen worden afgeweken van nagenoeg alle bepalingen van de eerste drie boeken van het Wetboek van Burgerlijke Rechtsvordering, van grote delen van de Wet op de Rechterlijke Organisatie, alsmede van de Faillissementswet, de Wet op de rechtsbijstand en de Wet griffierechten burgerlijke zaken. $\mathrm{Er}$ is een noodklep ingebouwd: de rechter kan toepassing van de experimenteerregels achterwege laten, indien die toepassing naar maatstaven van redelijkheid en billijkheid onaanvaardbaar is (art. 1 lid 4).

Elke AMvB moet eerst vier weken bij beide kamers van de Staten-Generaal worden 'voorgehangen'. De experimenten worden geëvalueerd, gevolgd door nieuwe wetgeving dan wel intrekking van de $\mathrm{AMvB}$. De experimenten hebben een maximale duur van drie jaar, de experimentenwet zelf geldt voor

\footnotetext{
Mr. P. Ingelse is mediator/arbiter bij ReulingSchutte te Amsterdam. Tot begin 2015 was hij lid van het Gerechtshof Amsterdam, laatstelijk als voorzitter van de Ondernemingskamer.

1. Formeel de Kroon, art. 89 lid $1 \mathrm{Gw}$.

2. Met memorie van toelichting te vinden op www.internetconsultatie.nl/ experimenten.

3. MvT, p. 1.
}

onbepaalde tijd. Het zijn slechts zes bepalingen, maar met grote impact.

\section{Aanleiding en doel}

De Raad voor de rechtspraak heeft per brief aan de kabinetsinformateur om een experimenteerbepaling gevraagd. ${ }^{4} \mathrm{Het}$ consultatievoorstel is daar - via het regeerakkoord ${ }^{5}$ - het voortvarende resultaat van.

Volgens de memorie van toelichting bij het voorstel moet er meer maatwerk komen. ${ }^{6}$ De rechtspraak moet in staat zijn om adequaat te reageren op de wisselende behoeften van mensen en hun wisselende vermogen om conflicten op te lossen.' Burgers zouden wel zelf willen procederen en zelf de regie voeren, maar men 'voelt (...) zich al snel genoodzaakt om een advocaat of andere procesvertegenwoordiger (...) in te schakelen'. Daarnaast dwingt het one size fits all-model tot procedurele (zij)stappen waar in de concrete zaak geen behoefte aan bestaat. Dat leidt tot 'meer complexiteit en uitdijing'. Het zijn 'de juridische schermutselingen die een procedure lang en ingewikkeld maken'. Tussenvonnissen met bewijsopdrachten, incidenten zoals een voorlopige voorziening, zij zorgen ervoor 'dat partijen uiteindelijk hun aanvankelijke geschil niet meer herkennen'. En dan drijven partijen de conflicten ook nog juridisch op de spits en graven zich in, in plaats van te zoeken naar een gezamenlijke oplossing. Dat is al helemaal niet goed in duurrelaties zoals bij huur en werk. Daarom is er 'behoefte aan eenvoudigere en snellere procedures en aan methoden om partijen in de loop van de procedure dichter bij elkaar te brengen en te voorkomen dat het conflict verder op de spits wordt gedreven'. Schikkingen bieden doorgaans een duurzamere oplossing en 'de rechter kan partijen helpen tot een vergelijk te komen en als dat niet lukt, snel uitspraak doen. Zo kan rechtspraak er wezenlijk toe doen in de samenleving.

\footnotetext{
4. Zie www.rechtspraak.nl/SiteCollectionDocuments/aanbevelingenkabinetsbeleid-de-rechtspraak.pdf.

5. 'Vertrouwen in de toekomst' van 10 oktober 2017, zie www. rijksoverheid.nl/documenten/publicaties/2017/10/10/regeerakkoord -2017-vertrouwen-in-de-toekomst.

6. Zie voor de hierna volgende citaten MvT, p. 4.
} 


\section{De beoogde grenzen}

Van afwijking zijn uitgezonderd de artikelen 1-14, 19-22 en 25-30 Rv ${ }^{7}$ en de artikelen 1-5, 7, 11-39, 76 en 84-109 Wet RO. De afwijking moet blijven binnen de grenzen van de fundamentele beginselen van procesrecht: het recht op / de beginselen van toegang tot de rechter, een eerlijk proces door een onafhankelijke en onpartijdige rechter, hoor en wederhoor, openbaarheid, de redelijke termijn en de goede procesorde (art. 1 lid 2). Dat geldt voor de eventueel afwijkende bepalingen, voor de opzet van ieder experiment en voor iedereen die met de uitvoering van een experiment zal zijn belast. Een opdracht derhalve aan de AMvB-regelgever, aan de plannenmakers bij de Raad voor de rechtspraak en de gerechten én aan de toepassende rechter. Artikel 1 lid 3 bepaalt voorts dat niet mag worden afgeweken van verdragen en van EU-recht. Daartoe behoort vanzelfsprekend ook artikel 6 EVRM. ${ }^{8}$ Verder valt de denken aan de betekenings-, bewijs- en executieverdragen en -verordeningen. ${ }^{?}$

\section{De experimenten: voorbeelden van de memorie van toelichting}

De memorie van toelichting oppert onder meer het inleiden van de procedure per formulier, het verruimen van de mogelijkheid in persoon te procederen, een schuldenrechter die alle zaken van een schuldenaar geconcentreerd behandelt ${ }^{10}$ en het voorschrijven dat de grieven in hoger beroep in de dagvaarding worden opgenomen. ${ }^{11}$ Denkbaar is een experiment met betrekking tot ontruimingsvorderingen tussen woningbouwverenigingen en huurders in het arrondissement Den Haag met het oog op bekorting van de doorlooptijden. Experimenten kunnen dwingend, facultatief of vrijwillig zijn. ${ }^{12}$ 'Facultatief betekent dat de keuze aan de eiser/verzoeker is. De gedaagde/verweerder is aan die keuze gebonden. ${ }^{13}$

De memorie van toelichting noemt in het bijzonder de volgende experimenten. ${ }^{14}$

7. Waar ik naar bepalingen in het Wetboek van Burgerlijke Rechtsvordering verwijs, hanteer ik de op dit moment geldende versie voor niet digitaal procederen, tenzij ik uitdrukkelijk KEI vermeld. De versie digitaal procederen geldt op dit moment alleen voor de pilot civiele handelsvorderingen met verplichte procesvertegenwoordiging bij de Rechtbanken Gelderland en Midden-Nederland. Voor het overige was KEI in april on hold gezet (brief van 13 april 2018 van de minister voor Rechtsbescherming aan de voorzitter van de Tweede Kamer, Kamerstukken II $2017, / 18,29279,420)$. Inmiddels heeft dit met het oog op de digitalisering geleid tot een reset (brief van 28 juni 2018 van de voorzitter van de Raad voor de rechtspraak an de minister voor Rechtsbescherming). Voor de experimentenwet hoeft dit niet uit te maken. De MvT noemt $\mathrm{KEI}$ in het geheel niet.

8. MvT, p. 8 en 10.

9. MvT, p. 10 en 11 .

10. MvT, p.7.

11. MvT, p. 14. Het laatste zal ongetwijfeld zijn bedoeld met 'experimenten (om) te onderzoeken hoe en wanneer in de procedure de grieven tegen het vonnis in eerste aanleg opgesteld moeten worden'.

12. MvT, p. 14.

13. MvT, p. 14 .

14. De Raad voor de rechtspraak vindt het geven van voorbeelden niet nodig. Liever alleen 'hoofdlijnen'. Hij heeft ook aarzelingen bij de MKBrechter in de voorgestelde vorm. Zie reactie $\operatorname{RvdR} \$ 7$.

\subsection{De MKB-rechter 15}

Volgens de memorie van toelichting hebben ondernemers in het midden- en kleinbedrijf (MKB) onderling behoefte aan eenvoudige procedures waarin sneller een finale beslissing verkregen kan worden, zodat zij weer zaken kunnen doen. Noch kort geding (beperkte mogelijkheden en niet finaal), noch bodemprocedure (complex en langdurig) kunnen dat bieden. Zo'n procedure kan worden bereikt door de schriftelijke stukken in formuliervorm op te laten stellen en onder meer voor te schrijven dat bewijs onmiddellijk bij procesinleiding respectievelijk reactieformulier wordt overgelegd, door geen verder getuigenbewijs of deskundigenbericht toe te laten, door de verplichte procesvertegenwoordiging voor gedaagde dan wel beide partijen op te heffen en door hoger beroep en cassatie uit te sluiten. Varianten op dit thema: verwijzingsmogelijkheid naar de normale procedure als meer bewijs aangewezen lijkt of - ter compensatie van het uitsluiten van hoger beroep en cassatie - de mogelijkheid binnen drie maanden na het vonnis van de MKB-rechter een gewone bodemprocedure te starten.

\subsection{De deskundige lekenrechter ${ }^{16}$}

Artikel 4 van het consultatievoorstel introduceert de deskundige lekenrechter. Deze experimenteermogelijkheid is in de wet zelf opgenomen, omdat artikel $116 \mathrm{Gw}$ een wettelijke grondslag voorschrijft. ${ }^{17}$

De memorie van toelichting wijst op tijdrovende complicaties die de inschakeling van deskundigen op de voet van artikel $194 \mathrm{Rv}$ mee kunnen brengen, zoals diverse tussenvonnissen, conceptrapportage, schriftelijke reactie op definitieve rapportage. In een regiezitting zouden partijen en de rechter daarom afspraken moeten kunnen maken over de toevoeging van een deskundig lid, een lekenrechter, aan de kamer. De rechter zou dat ook ambtshalve moeten kunnen doen. De naast de unus dan wel in de meervoudige kamer toegevoegde rechter 'neemt op dezelfde wijze deel aan de procedure als de rechter en is medebeslisser'. ${ }^{18}$ De memorie van toelichting denkt met name aan zaken op het gebied van het bouwrecht of letselschadezaken.

\subsection{De alternatieve echtscheidingsprocedure $e^{19}$}

In zijn rapport 'Scheiden... En de kinderen dan?'20 stelt het Platform scheiden zonder schade onder leiding van André Rouvoet - naast meer maatwerk en de regierechter - voor te experimenteren met een alternatieve echtscheidingsprocedure. Onder verwijzing naar dit rapport presenteert de memorie van toelichting de mogelijkheid van een experiment 'met een alternatieve laagdrempelige snelle toegang tot de familierechter en een meer op de belangen van het gehele gezin gerichte rechtsgang voor echtscheidingszaken'. De procedure moet de echt-

15. MvT, p. 15 e.v.

16. MvT, p. 17 e.v.

17. MvT, p. 7 en 23.

18. MvT, p. 18.

19. MvT, p. 19 e.v.

20. Zie www.rijksoverheid.nl/documenten/rapporten/2018/02/22/rapportscheiden...en-de-kinderen-dan. 
scheiding 'op zo harmonieus mogelijke wijze' laten verlopen. Daarbij zou 'een neutrale gezinsvertegenwoordiger' betrokken kunnen worden. Deze zal in de procedure de belangen van alle gezinsleden in het oog moeten houden en ervoor waken dat deze niet uit balans raken. De procedure zou kunnen beginnen met één gezamenlijk processtuk van beide ouders. Zijn er kwesties waar33 de ouders niet uitkomen, dan moet de rechter 'door een snelle beslissing knopen kunnen doorhakken, zodat daarna de weg vrij is voor de ouders om hun gesprekken over andere aspecten van de echtscheiding voort te zetten'.

Het Platform wil daarvoor een rechter die is opgeleid ouders te stimuleren 'om te komen tot compromissen die voor ieder werkbaar zijn' en die wordt bijgestaan door een gedragswetenschapper. Het gaat om 'het vinden van een dialogische ruimte, binnen de randvoorwaarden van de beginselen van due process, rechtsgelijkheid en rechtszekerheid'. De belangen van het kind staan centraal. ${ }^{21}$

\section{De reacties op de consultatie}

Tot 1 juni 2018 kon ieder die dat wilde - al dan niet openbaar - reageren op het consultatievoorstel. Er zijn vijf openbare reacties op de website verschenen. ${ }^{22}$ Eén reactie wijst op de veel voorkomende samenhang tussen bestuursrechtelijke en civielrechtelijke verhoudingen en oppert de mogelijkheid de ene procedure te 'converteren' in de andere. ${ }^{23}$ Een tweede wijst het voorstel als te globaal af. ${ }^{24}$ Een derde mist de bevoegdheid van de rechter 'zelf op zoek te gaan naar de waarheid'. ${ }^{25} \mathrm{HiiL}^{26}$ is positief over het voorstel. Het instituut bouwt met weidse bespiegelingen voort op eerdere rapporten, onder meer het rapport 'Menselijk en rechtvaardig, Is de rechtsstaat er voor de burger?' van mei 2017. ${ }^{27}$ In verband met 'multiproblematiek' en 'stapeling' van zaken wil HiiL de wet uitbreiden naar het strafrecht en het bestuursrecht. HiiL wijst erop dat vernieuwing in het verleden vaak is bemoeilijkt 'door wensen van deurwaarders, advocaten, rechtbanken en procesrechts-deskundigen om huidige rollen te behouden'. De Vereniging Sociale Advocatuur Nederland (VSAN) wijst het voorstel af. Zij vreest verkapte bezuinigingen. Haar argwaan wordt gevoed doordat de minister van Justitie en Veiligheid de afgelopen jaren verschillende pogingen heeft ondernomen substantieel te korten op de kosten van rechtsbijstand, terwijl er volgens de Commissie-Van der Meer juist $€ 127$ miljoen bij moet.

21. Zie de ontwikkelpunten, elders in het rapport uitgewerkt en toegelicht, t.a.p. p. 23.

22. www.internetconsultatie.nl/experimenten/reacties.

23. L.M. Koenraad, rechter-plaatsvervanger Rechtbank Gelderland.

24. M. J. Husen, advocaat te Rotterdam.

25. F. Nijhof te Huizen.

26. The Hague Institute for Innovation of Law, zie www.hiil.org.

27. www.hiil.org/insight/menselijk-en-rechtvaardig-is-de-rechtsstaat-er-voorde-burger-report. Zie daarover Lieke Coenraad en Peter Ingelse, 'Rechter, mediator en innovatie: een uitdaging', in Tijdschrift Conflicthantering, 2017, afl. 5, p. 18 e.v.
Naast deze reacties op de website zijn er ook drie openbare reacties. De Hoge Raad publiceerde een reactie op rechtspraak. $\mathrm{nl}^{28}$ Het college ondersteunt het streven in het consultatievoorstel om 'via een wettelijke regeling mogelijk te maken dat nieuwe varianten voor civiele procedures proefondervindelijk worden onderzocht op hun mogelijke bijdrage aan een effectieve en efficiënte rechtspleging. ${ }^{29}$ Voorts gaat de Hoge Raad uitvoerig in op de hardheidsclausule van artikel 1 lid 4 van het consultatievoorstel.

De Nederlandse Orde van Advocaten (NOvA) heeft een reactie van haar Algemene raad met advies van vier van haar adviescommissies gepubliceerd. ${ }^{30}$ De NOvA 'onderschrijft het nut van het (wettelijk) mogelijk maken van experimenten in de rechtspleging. ${ }^{31} \mathrm{Zij}$ stelt voor ook de artikelen 15 tot en met 18 alsmede 23 en $24 \mathrm{Rv}$ van afwijking uit te zonderen. ${ }^{32}$ Ook zij wijst op de conclusies van de Commissie-Van der Meer en op het 'achterstallige onderhoud' in de gefinancierde rechtshulp. Zij heeft ook op andere punten kritiek.

Bij brief van 20 juni 2018 van zijn voorzitter bracht de Raad voor de rechtspraak advies aan de minister voor Rechtsbescherming uit. ${ }^{33}$ De Raad acht 'de gekozen opzet (...) werkbaar. ${ }^{34}$ Het klinkt wat zuinigjes, maar uit de verdere reactie blijkt dat de Raad het consultatievoorstel in hoofdzaak steunt. De Raad wil het doel uitbreiden: hij acht ook experimenten wenselijk die 'bijdragen aan een de-escalatie van het onderliggende conflict en die de conflictoplossende werking van rechterlijke interventies versterken'. ${ }^{35}$ De Raad wil een bredere toepasselijkheid: niet alleen eenvoudige zaken. Voorts wil hij uitbreiding met artikel $1065 \mathrm{Rv}$ (gronden voor vernietiging van arbitrale vonnissen) en met enkele bepalingen uit het BW om een echtscheidingsprocedure en geschillen over kinderen zonder inleidende stukken mogelijk te maken. Omgekeerd zou de experimentabiliteit van de Faillissementswet tot de procedurele bepalingen moeten worden beperkt. ${ }^{36}$ De Raad wil dat de experimenten in beginsel dwingend zijn. ${ }^{37}$

\section{Commentaar op het consultatievoorstel}

\subsection{Nieuwe en oude experimenten en innovatie}

In de afgelopen jaren is al heel wat afgeëxperimenteerd. Ik noem met name de pilots Burenrechter bij de Rechtbank Midden-Nederland (locatie Utrecht) en de Rechtbank Oost-

28. Zie www.rechtspraak.nl/Organisatie-en-contact/Organisatie/Hoge-Raad -der-Nederlanden/Documents/Advies\%20Experimentenwet \%20rechtspleging.pdf.

29. Reactie HR, p. 2.

30. Zie www.advocatenorde.nl/juridische-databank/details/wetgevingsadvie zen/83078.

31. Reactie NOvA, p. 5.

32. Reactie NOvA, $\$ 4.2$ en 4.3 .

33. www.rechtspraak.nl/SiteCollectionDocuments/2018-22-adviesexperimentenwet-rechtspleging.pdf.

34. Reactie RvdR, $\$ 1$.

35. Reactie RvdR, p. 3.

36. Reactie RvdR, p. 3 en 4.

37. Reactie $\operatorname{RvdR}, \$ 5$. 
Brabant, ${ }^{38}$ de pilot Spreekuurrechter bij de Rechtbank NoordNederland ${ }^{39}$ en de e-kantonrechter ${ }^{40}$. Deze experimenten werden uitgevoerd op de grondslag van artikel 96 Rv. ${ }^{41}$

Maar geëxperimenteerd en geïnnoveerd wordt er al veel langer. Denk aan de ontwikkelingen in het kort geding. In Rotterdam drukte de president J.G.L. Reuder ${ }^{42}$ in de jaren zestig en zeventig van de vorige eeuw zijn stempel op het kort geding: een directe vorm van behandeling aan de tafel van de president in zijn kamer, met veel schikkingen tot resultaat. In Amsterdam ontpopte B.J. Asscher ${ }^{43}$ zich in de jaren tachtig van de vorige eeuw als actieve rechter die de kort-gedingprocedure stroomlijnde, de mogelijkheid creëerde het kort geding te combineren met een voorlopig getuigenverhoor, niet te beroerd was de zitting te onderbreken voor een - onmiddellijke - descente en als dorpsoudste eveneens actief op schikkingen aanstuurde.

In de jaren tachtig van de vorige eeuw werd voorts geëxperimenteerd met de comparitie na antwoord. $\mathrm{Zij}$ werd geleidelijk overal ingevoerd, lang voordat zij in 1989 facultatief $^{44}$ en in 2002 als standaard in de wet werd vastgelegd. ${ }^{45}$ We kennen inmiddels de comparitie na aanbrengen in hoger beroep, ${ }^{46}$ het ter zitting gegeven voorlopig oordeel ook in bodemzaken, ${ }^{47}$ diverse mediation pilots ${ }^{48}$ en de videorechter in bewindzaken

38. www.rechtspraak.nl/Organisatie-en-contact/Organisatie/Rechtbanken/ Rechtbank-Oost-Brabant/Regels-en-procedures/Paginas/deburenrechter.aspx.

39. Zie www.rechtspraak.nl/spreekuurrechter en A.H.J Lennaerts, 'De Spreekuurrechter', NJB 2016, p. 802 ev. Zie voor kritische kanttekeningen onder meer E. Mak, 'De Spreekuurrechter: een nuttige innovatie?', Ars Aequi, 2017, p. 29 e.v.

40. Sinds juni 2014 was het mogelijk online te procederen voor de kantonrechter. Dit is in het kader van het on hold zetten van KEI in april van dit jaar 'direct beëindigd'. Zie de brief van 10 april 2018 van de voorzitter van de RvdR aan de minister voor Rechtsbescherming: www. rechtspraak.nl/SiteCollectionDocuments/2018-brief-reset-digitalisering pdf, p. 5.

41. Zie over de mogelijkheden die art. $96 \mathrm{Rv}$ biedt onder meer N. Mirzojan, Omgekeerde prorogatie. Artikel 96: rechtspraak op maat middels 'arbitrage' bij de kantonrechter, Celsus juridische uitgeverij 2017.

42. Zie over hem en het kort geding G.Chr. Kok, Rotterdamse juristen uit vijf eeuwen, Rotterdams Juridisch Genootschap en Stichting Historische Publicaties Roterodamum, 2009, p. 351 e.v.

43. Zie over hem bijvoorbeeld de aan hem bij zijn afscheid aangeboden bundel Kabaal in Holland, Gouda Quint 1993.

44. Art. 141a Rv, ingevoerd bij wet van 25 oktober 1989, Stb. 1989, 483.

45. Art. $131 \mathrm{Rv}$, ingevoerd bij de wet van 14 december 2001, Stb. 2001, 623.

46. Bijvoorbeeld: www.rechtspraak.nl/Organisatie-en-contact/Orga nisatie/ Gerechtshoven/Gerechtshof-Amsterdam/Regels-procedures-enklachten/Paginas/CnA-bijlage-Amsterdam.aspx.

47. Zie voor deze mogelijkheid bij bijvoorbeeld het Haags gerechtshof: www.rechtspraak.nl/Organisatie-en-contact/Organisatie/ Gerechtshoven/Gerechtshof-Den-Haag/Regels-procedures-en-klachten/ Paginas/Werkwijze-comparitie-na-aanbrengen-gerechtshof-Den-Haag. aspx.

48. Bijvoorbeeld GOO (Gericht op oplossing) in de Rechtbank Amsterdam: www.rechtspraak.nl/Organisatie-en-contact/Organisatie/Recht banken/Rechtbank-Amsterdam/Regels-en-procedures/Paginas/ Procedure-Gericht-Op-Oplossing.aspx. Zie over mediation en innovatie Lieke Coenraad en Peter Ingelse, 'Rechter, mediator en innovatie: een uitdaging', Tijdschrift Conflicthantering, 2017, afl. 5, p. 18 ev. in de Rechtbank Noord-Nederland ${ }^{49}$. En ik mis ongetwijfeld nog vele andere initiatieven. Het onderscheid tussen experimenteren en gewoon dóen is niet scherp. Reuder en Asscher zagen hun innovatie vermoedelijk niet als een experiment, misschien zelfs niet als innovatie, zij deden het gewoon. En al deze experimenten droegen in zich wat ook nu wordt nagestreefd: praktisch, dicht bij de burger, informeel, toegankelijk, flexibel, snel, op oplossing gericht.

\subsection{Noodzaak en aanvaardbaarheid van experimenten en van een experimentenwet}

Waar verbeteringen gewenst zijn, moet verbeterd worden. Dat vergt - kort gezegd - creativiteit, onderzoek, reflectie, waar nodig uitproberen, doorzettingsvermogen, soms moed en meestal: geld.

Niet voor iedere ontwikkeling - of je die nu de modieuze kwalificatie 'innovatie' meegeeft of niet - is een experiment nodig. ${ }^{50}$ Maar het komt voor dat onderzoek en reflectie te veel onzekerheid laten. Dan kan uitproberen een optie zijn, op voorwaarde dat een proefneming toelaatbaar en in de gegeven omstandigheden aanvaardbaar is. Voormelde experimenten en pilots en andere proeven en tests hebben hun nut bewezen. En ook met wettelijke experimenteerbepalingen is veel ervaring opgedaan. ${ }^{51}$ Maar zijn op zichzelf wenselijke experimenten ook steeds aanvaardbaar? En zo ja, moeten dan eventuele wettelijke belemmeringen worden opgeheven? In een raamwet en op de ruime wijze zoals voorzien in het consultatievoorstel? Hoe zit het met de staatsrechtelijke verhoudingen? Volgens de toelichting bij aanwijzing 2.41 van de Aanwijzingen voor de regelgeving moet niet 'te snel' tot een experimentele regeling worden overgegaan, 'mede gelet op het gelijkheidsbeginsel en het rechtszekerheidsbeginsel'. Jacobs wijst erop dat terughoudendheid volgens wetgevingsjuristen en volgens de Raad van State op zijn plaats is. ${ }^{52}$ Die houding vind je in de memorie van toelichting niet terug: bespreking van dergelijke algemene vragen blijft (vrijwel) achterwege. ${ }^{53}$ De noodzakelijke afwegingen worden zonder verdere instructie aan de AMvB-regelgever overgelaten. De Hoge Raad en de Raad voor de rechtspraak constateren vooral dat het consultatievoorstel in een behoefte voorziet en dat de voorbereiding van een $\mathrm{AMvB}$ zorgvuldig moet zijn, maar gaan in hun reacties niet op deze algemene vragen in. ${ }^{54} \mathrm{Ik}$ zal een aantal van de vragen bespreken.

49. Zie www.rechtspraak.nl/Organisatie-en-contact/Organisatie/Rechtbank en/Rechtbank-Noord-Nederland/Regels-en-procedures/Paginas/ Videorechter.aspx.

50. Zo ook de MvT, p. 5.

51. M.J. Jacobs geeft in haar oratie een opsomming. Zie Experimentele wetgeving, Deventer: Wolters Kluwer, 2018 p. 19.

52. T.a.p. p. 15 .

53. De memorie van toelichting merkt op p. 12 wel op dat 'enige mate van rechtsongelijkheid inherent is aan het uitvoeren van experimenten in de procesvoering'. Die 'geringe mate van rechtsongelijkheid' blijft 'binnen duidelijke en acceptabele grenzen (...)'. Dat het slechts om een geringe ongelijkheid gaat, wordt niet uitgelegd.

54. Wel nodigt de Hoge Raad de wetgever uit uiteen te zetten hoe het voorstel zich verhoudt tot aanwijzingen 2.41 en 2.42 van de Aanwijzingen voor de regelgeving. 
Is een experimentenwet noodzakelijk en wenselijk? Al die experimenten en innovaties in het verleden konden worden uit- respectievelijk ingevoerd zonder zo'n wet. Sommige belemmeringen voor verdere experimenten worden opgeheven door de invoering van KEI. ${ }^{55}$ Het is wat curieus om gedurende deze majeure operatie te klagen over 'het one size fits allmodel', dat leidt tot 'meer complexiteit en uitdijing', en te vragen om meer maatwerk. ${ }^{56}$ Dat wilde KEI toch juist bieden? Moeten we dat niet eerst uitproberen? De zaaks- en regierech$\operatorname{ter}^{57}$ moeten zeer wel in staat zijn om allerlei chicanes met onbevoegdheids- en vrijwaringsincidenten of onnodige getuigen de kop in te drukken. ${ }^{58}$ En, als je vergelijkend onderzoek wilt doen, is daar nu een fraaie gelegenheid voor: vergelijk de oude procedure met de nieuwe, die is ingevoerd in de Rechtbanken Midden-Nederland en Gelderland. Voor al die experimenten is een raamwet niet nodig. ${ }^{59}$

Het voorgaande neemt niet weg dat niet álles kan, ook niet na invoering van KEI. Daar waar partijen niet van de processuele regels kunnen afwijken - en dus artikel $96 \mathrm{Rv}$ niet de basis voor experimenteren biedt - gaat het vaak om zwaarwegende belangen, die zich niet voor een experiment lenen en daarom zijn aangewezen op keuzes zonder test. Indien in een bepaald geval een weloverwogen keuze moeilijk zonder experiment kan worden gemaakt, kan daaraan afzonderlijke wetgevende aandacht worden besteed. ${ }^{60}$

Het consultatievoorstel biedt daarnaast een algemene mogelijkheid voor experimenten. Er kan zeer veel: termijnen verkorten of verlengen, ${ }^{61}$ het schrappen van de bevoegdheid incidenten op te werpen ${ }^{62}$ of van de mogelijkheid om te wraken en te verschonen, ${ }^{63}$ het versoepelen of juist beperken van beslag- en executiemogelijkheden, het vervangen van de betrokken regels of het op onderdelen afwijken ervan. Verplichte procesvertegenwoordiging? ${ }^{64}$ Hoeft niet. Getuigenbe-

55. Denk bijvoorbeeld aan de in art. 112 lid $1 \mathrm{Rv}$ (KEI) geschapen mogelijkheid voor de eiser om ter inleiding van een procedure de wederpartij bij brief op te roepen.

56. MvT, p. 4, hiervoor ook al geciteerd.

57. Zie daarover uitvoerig Lieke Coenraad en Peter Ingelse, Afscheid van de klassieke civiele procedure? Preadvies voor de Nederlandse Juristen Vereniging 2017 (http://njv.nl/wp-content/uploads/2017/04/PreadviezenNJV-2017.pdf), verder: preadvies, hoofdstukken 4 en 5.

58. KEI is weliswaar gereset (zie een eerdere noot), maar dat betreft met name het IT-systeem en aangenomen mag worden dat de nieuwe bepalingen van het Wetboek van Burgerlijke Rechtsvordering alsnog binnen afzienbare tijd worden ingevoerd. En ook zonder dat staat - behalve wellicht de kosten - niets aan invoering van regie- en maatwerk in de weg.

59. Zie ook Jacobs t.a.p. p. 55.

60. Jacobs t.a.p. p. 31: voor een afzonderlijke experimenteerwet 'wordt gekozen als de te treffen experimenten een ingrijpend karakter hebben zodat gelet op de aard van de materie delegatie niet in aanmerking komt'.

61. Uiteraard tenzij dit afbreuk zou doen aan hoor en wederhoor.

62. MvT, p. 2 en 14.

63. De Raad voor de rechtspraak is daarvan geen voorstander. Zie de reactie in de bijlage met wetstechnisch commentaar.

64. MvT, p. 14, 16, 17 en 20.

65. MvT, p. 13, 16 en 17. Er bestaat in civilibus niet in zijn algemeenheid een recht op twee instanties: HR 26 november 1999, NJ 2000/244. wijs kost te veel tijd? Hoger beroep ${ }^{65}$ ook? Wij schrappen het. Het is allemaal 'afwijken'.

U zegt: 'Je kunt goed overdrijven.' Ik weet het niet, ik denk dat er ook lezers zijn die zeggen: 'Eigenlijk wel goede ideeën.' Wellicht behoren de laatsten straks tot de plannenmakers. Bovendien, voor de meeste van deze afwijkingen valt onder omstandigheden ook wel wat te zeggen en een aantal komt uitdrukkelijk in de memorie van toelichting aan bod, met name in verband met de MKB-procedure.

In feite wordt - binnen de besproken grenzen - carte blanche gegeven. En dat is ook uitdrukkelijk de bedoeling: volgens de memorie van toelichting moet voorkomen worden 'dat in de toekomst experimenten onverhoopt oplopen tegen artikelen waarvan afwijking bij de Experimentenwet niet is voorzien'. ${ }^{66}$

Het Wetboek van Burgerlijke Rechtsvordering biedt meer dan de fundamentele beginselen: ondanks alle kritiek die mogelijk is, vormt het een doordacht, hecht samenhangend bouwwerk. Het verdient mijns inziens geen aanbeveling om dat bouwwerk zo algemeen aan experimenten bloot te stellen: de bepalingen van de betrokken wetten zouden aan de hand van te ontwikkelen criteria stuk voor stuk bezien moeten worden op hun geschiktheid voor experimenten en de aanvaardbaarheid daarvan. Die criteria zal ik aanstonds bespreken.

Voor wie is deze carte blanche nodig, voor de rechter, de minister voor Rechtsbescherming, de wetgever? De laatste hééft die ruimte, die heeft geen verdere bevoegdheden nodig. De rechter kán experimenteren binnen zijn bevoegdheden, wij zagen dat al. Gerechtsbesturen en de Raad voor de rechtspraak kunnen experimenten faciliteren of bevorderen op de voet van artikel 23 respectievelijk 94 Wet RO. Blijft over de minister voor Rechtsbescherming. Mij gaat de vrijwel ongeclausuleerde toepasbaarheid voor nu en over twintig jaar en nog langer ${ }^{67}$ te ver. De NOvA wil de geldigheidsduur van de wet beperken tot zes jaar. ${ }^{68}$

Maar past de rol van experimentenbedenker en/of uitvoerder op het terrein van de rechtspraak de minister eigenlijk wel? Het consultatievoorstel brengt het initiëren van experimenten en de inrichting van ons burgerlijk procesrecht voor experimenten over de volle breedte ${ }^{69}$ in de bestuurlijke sfeer. Het komt mij voor dat dit uit een oogpunt van rechtstatelijke verhoudingen niet gewenst is. In plaats daarvan zou de rol van de Raad voor de rechtspraak versterkt kunnen worden. Daarbij kan worden gedacht aan het leggen van het initiatief bij de Raad voor de rechtspraak of aan een vorm die aansluiting zoekt bij de Wet medisch-wetenschappelijk onderzoek. De

66. MvT, p. 5. Zie ook p. 14 en 21.

67. De MvT wil uitdrukkelijk voorkomen dat 'in de toekomst experimenten onverhoopt oplopen tegen artikelen waarvan afwijking bij de Experimentenwet niet is voorzien'. Zie p. 5. Zie ook p. 8, 20 en 23.

68. Reactie NOvA, $\$ 2$ sub 4 .

69. Met inachtneming van EU-recht, verdragen en de fundamentele beginselen van procesrecht, maar dat doet hier niet aan af. 
Hoge Raad doet in zijn reactie een vergelijkbare suggestie. ${ }^{70}$ De Raad voor de rechtspraak sluit zich bij die suggestie aan. ${ }^{71}$

Ik voeg in dit verband de vraag toe of de bijna ongeclausuleerde afwijkingsmogelijkheid van het Wetboek van Burgerlijke Rechtsvordering niet de codificatietaak van artikel $107 \mathrm{Gw}$ ten aanzien van het burgerlijk procesrecht ten behoeve van experimenten in handen van de AMvB-regelgever legt. Ik ben geen kenner van het staatsrecht en ik geloof dat 'regelen' een ruim begrip is, maar een carte blanche in delegatie, die het procesrecht blootstelt aan soms door de waan van de dag opgestuwde experimenten, lijkt mij op zijn minst strijdig met de strekking van deze grondwettelijke bepaling. En opent het wetsvoorstel niet de mogelijkheid de burger 'tegen zijn wil (af te houden) van de rechter die de wet hem toekent' ${ }^{72}$ Een afweging op dit punt zoals voorgeschreven in de Aanwijzingen voor de regelgeving ${ }^{73}$ vond ik niet in de memorie van toelichting.

\subsection{Criteria voor experimenten}

Sommige regels geven de rechter veel ruimte voor de inrichting van de procedure, bijvoorbeeld het uitstel van proceshandelingen. Dat biedt de mogelijkheid tot nadere regelgeving (procesreglementen), maar ook tot experimenteren met bijvoorbeeld korte, strakke termijnen. Daar zie ik in het algemeen weinig bezwaar tegen: de rechter maakt slechts gebruik van de hem gegeven bevoegdheden. De fundamentele beginselen van procesrecht en EU-recht vormen de ondergrens. Het consultatievoorstel sluit daarmee strijdige experimenten uit. Maar daartussen is zeer veel mogelijk. Zijn nadere grenzen te trekken?

De memorie van toelichting geeft zelf een voorbeeld: het moet gaan om verbetering van de procesvoering 'met het oog op de behoefte van rechtzoekende burgers en bedrijven aan meer eenvoud, snelheid, flexibiliteit en effectiviteit bij gerechtelijke procedures. ${ }^{74}$ Opvallend is dat deze woorden niet in de memorie terugkeren, waar je dat wel zou verwachten. $\mathrm{Zij}$ vormen niettemin een beperking: pure bezuinigingsexperimenten of capaciteitsexperimenten ${ }^{75}$ passen niet binnen deze maatstaf. In de toelichting op elke AMvB én in de voorgeschreven evaluatie, zal moeten worden uiteengezet hoe de behoeftes van de burgers en bedrijven worden gediend. Eenvoudig is dat niet: de woorden geven weinig richting. Wat is een 'verbetering' van de procesvoering? En om de behoeftes van welke burgers en van welke bedrijven gaat het $?^{76}$ Eenvoud, snelheid, flexibiliteit en effectiviteit lijken een harmonieus kwartet te vormen, dat wil toch iedereen? Deze aspecten kunnen elkaar echter bijten.

\footnotetext{
70. Reactie HR, p. 2.

71. Reactie RvdR, $\$ 2$.

72. Art. $17 \mathrm{Gw}$, zie reactie NOvA , $\$ 8.1$ en 8.2 .

73. Aanwijzingen voor de regelgeving, zoals met ingang van 1 januari 2018 gewijzigd (Stcrt. 2017, 69426), aanwijzing 2.15.

74. MvT, p. 1.

75. MvT, p. 11.

76. Zie voor een relativering van de behoefte van burgers en bedrijven of 'wensen van de klant' preadvies, $\$ 3.3$.
}

Flexibiliteit en effectiviteit kunnen het royaal toelaten van bewijs en incidenten vragen. Maar eenvoudiger en sneller wordt het er niet op, zoals de memorie van toelichting terecht constateert. ${ }^{77}$ Ook in een simpele zaak moet soms over de bevoegdheid van de rechter worden beslist of kan het effectief zijn zaken te voegen of een belanghebbende tot de procedure toe te laten.

Zijn er nog andere criteria te bedenken? In de geneeskunde en de farmacie mag doorgaans niet worden geëxperimenteerd zonder dat de proefpersoon daarmee heeft ingestemd. ${ }^{78}$ Bovendien verbindt de wet aan het uitvoeren van experimenten toezicht door een commissie van deskundigen, medici, juristen en ethici. Ook het proefpersonen-perspectief is vertegenwoordigd. ${ }^{79}$ Voorts kent de wet een waslijst van kwaliteitscriteria, zoals subsidiariteit, proportionaliteit en minimalisering van risico's. ${ }^{80}$ Kunnen wij daarvan leren?

De memorie van toelichting verklaart dat rechtszoekenden geen proefdieren zijn $^{81}$, maar legt niet uit waarom zij niettemin - soms ook tegen hun zin $^{82}$ en eventueel per categorie ${ }^{83}$ in mogelijk ingrijpende experimenten kunnen worden betrokken. De Raad voor de rechtspraak wil zelfs dat de experimenten 'in beginsel dwingend' zijn. Dat voorkomt dat 'uit vertrouwdheid met de "normale" procedure te weinig gebruik wordt gemaakt van het experiment' ${ }^{84}$ Maar moet hier geen onderscheid worden gemakt: bepalingen die voor experimenten vatbaar zijn zonder respectievelijk slechts met instemming van (één van) partijen?

Ik geef een voorbeeld. Het burgerlijk procesrecht reikt de burger de middelen aan om zijn privaatrechtelijke rechten en verplichtingen te verwezenlijken. Sommige van die middelen zijn zo essentieel dat zij de betekenis van die materiële rechten en plichten mede bepalen. Zo moet je het bestaan van rechten en plichten kunnen bewijzen. De door de wet gegeven bewijsmiddelen bepalen aldus de effectiviteit van die rechten en plichten. Neem de eiser die weet dat hij zijn vordering alleen kan waar maken met getuigenbewijs. Hij moet de zaak voorleggen aan de Rechtbank Maastricht. Nooit eerder bij de rechter geweest, maar hij hoort dat daar een experiment loopt waarin getuigenbewijs alleen kan worden geleverd met schriftelijke verklaringen. Dat is pech: zijn getuigen willen hem niet te woord staan, laat staan iets opschrijven. Kan hij dan het beste afzien van zijn zaak en met lede ogen zien dat hij in Den Bosch zijn recht wel had kunnen halen? ${ }^{85}$ Of moet hij maar hopen

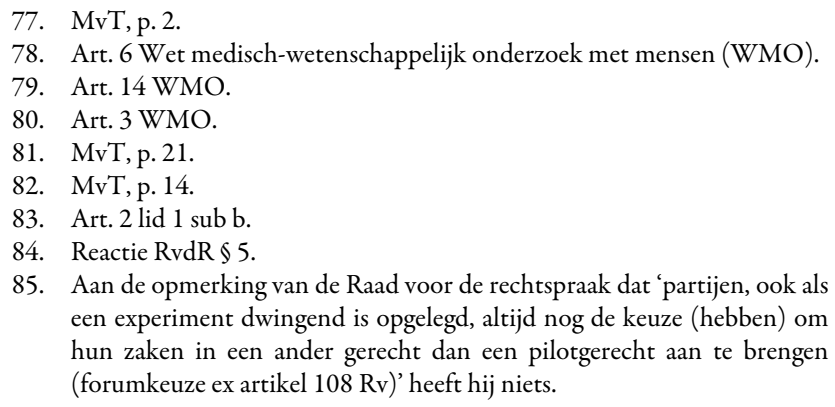

85. Aan de opmerking van de Raad voor de rechtspraak dat 'partijen, ook als een experiment dwingend is opgelegd, altijd nog de keuze (hebben) om hun zaken in een ander gerecht dan een pilotgerecht aan te brengen (forumkeuze ex artikel $108 \mathrm{Rv}$ )' heeft hij niets. 
dat de rechter oordeelt dat toepassing van het experiment 'naar maatstaven van redelijkheid en billijkheid voor (hem) onaanvaardbaar is'? Dan moet hij eerst wel een in beginsel kansloze procedure opzetten. En als de rechter de hardheidsclausule inderdaad toepast? Dan is het experiment meteen om zeep. Hij moet dan immers hetzelfde doen bij ieder ander die getuigen wil doen horen. Het zonder instemming van partijen uitsluiten of belemmeren van getuigenbewijs of deskundigenbericht acht ik dan ook niet aanvaardbaar. Het zou afbreuk (kunnen) doen aan de verwezenlijking van materiële rechten en verplichtingen en daarmee aan die rechten en verplichtingen zelf. Ook andere tegen de wil van partijen toe te passen experimenten zullen - waar zij de uitkomst materieel beïnvloeden - ongelijkheid en frustratie oproepen, zeker bij oneshooters.

Ik concludeer dat nadere reflectie op wenselijkheid en aanvaardbaarheid van experimenten, van een experimentenwet en van op in verband daarmee te ontwikkelen criteria noodzakelijk is. ${ }^{86}$

\section{Commentaar op de voorbeelden van de memorie van toelichting}

\subsection{De MKB-rechter}

De VSAN beklaagt zich erover dat het consultatievoorstel wel een experiment voor 'mondige' MKB'ers beschrijft maar niet voor procedures 'tussen ongelijkwaardige partijen (...), zoals bijvoorbeeld de overheid tegen de burger of grote bedrijven tegen burgers' ${ }^{87}$ Een tikkeltje kinderachtig: het is op zichzelf juist, maar vormt geen argument tegen het MKB-experiment. Wel vóór een experiment voor procedures 'tussen ongelijkwaardige partijen'.

Ook hier de vraag: is voor het MKB-experiment eigenlijk een wet nodig? Niet indien partijen voor deze procedure kiezen op de voet van artikel 96 Rv. Maar, aldus de memorie van toelichting, ${ }^{88}$ indien de verhouding tussen partijen is verslechterd, zal de verweerder vaak alleen al daarom niet met deze rechtsgang instemmen, ondanks het feit dat 'die beter aansluit bij de situatie en de behoeften van de partijen'. Met andere woorden: partijen willen het niet, terwijl het wel beter voor ze is. Dat klinkt tamelijk paternalistisch.

Maar los daarvan heb ik grote aarzelingen bij de gedachte deze procedure ter wille van een experiment en tegen de zin van (een van) partijen in te voeren. Een formulier in plaats van de klassieke dagvaarding of verzoekschrift ontmoet natuurlijk geen bezwaar. Experiment noch nadere wettelijke grondslag zijn daarvoor nodig. Zolang dat formulier maar vermeldt wat

86. Ook de NOvA acht de afwijkingsmogelijkheid te onbepaald en zoekt naar nauwkeuriger afgrenzing (wel: procedurele regels; niet: regels betreffende 'de samenstelling van de gerechten of het wijzigen van de rechtskracht of -gevolgen van rechterlijke beslissingen'. Zie reactie NOvA $\$ 8.2$ en 8.3 .

87. Reactie VSAN, p. 7.

88. MvT, p. 1. de wet voorschrijft. De uitsluiting van hoger beroep en cassatie vraagt om een keuze, niet om een experiment. ${ }^{89}$ De uitkomst van een dergelijk experiment is voorspelbaar: je hebt eerder een finale beslissing en er is meer kans dat de finale beslissing niet juist is. In het verleden kon de appèlgrens verhoogd worden zonder experiment.

Opheffing van de verplichte procesvertegenwoordiging? Eigenlijk geen slecht idee, het valt moeilijk uit te leggen waarom iemand zijn eigen belangen niet zelf mag verdedigen. De NOvA denkt hier - niet onverwacht - heel anders over. ${ }^{90} \mathrm{Zij}$ wil 'gelet op het fundamentele karakter van de toegang tot het recht' geen beperking van het procesmonopolie. Maar de toegankelijkheid vergt toch geen plicht tot, maar slechts een recht $o p$ rechtsbijstand? En dát is waar het hier om draait: bij opheffing of beperking van het procesmonopolie mag aan dat recht geen afbreuk worden gedaan. Ook hier geldt: het vraagt om een keuze, niet om een proef.

\section{a) De deskundige lekenrechter}

Uit ervaring in de Ondernemingskamer weet ik hoe vruchtbaar de deelneming van deskundige leden aan de rechtspraak kan zijn. ${ }^{91}$ In de Ondernemingskamer heeft ieder lid gelijke stem. Dat biedt het consultatievoorstel niet: het meebeslissen is schijn. Immers, bij het staken der stemmen 'geeft de stem van de rechterlijk ambtenaar onderscheidenlijk de rechterlijk ambtenaren de doorslag'. In de combinatie van twee of vier ${ }^{92}$ is geen stemming te bedenken waarin de stem van de bouwdeskundige of letselspecialist enige beslissende betekenis heeft. Zijn opvatting zal het in raadkamer uitsluitend 'winnen', wanneer zijn opvatting het ook zonder zijn stem zou hebben gehaald. Materieel vormt zijn bijdrage derhalve een advies. Als adviseur in raadkamer kan hij natuurlijk een belangrijke rol spelen, maar meer dan dat is hij niet.

Dat roept meteen de vraag op of dit niet in strijd is met het recht op hoor en wederhoor. Moeten partijen niet de gelegenheid krijgen op het advies van de lekenrechter te reageren? De professionele rechters betrekken het advies van de lekenrechter immers in hun oordeel. En precies dat was de ratio van het toelaten van de Borgersbrieven na de conclusie van de procureur-generaal bij de Hoge Raad. ${ }^{93}$ En ik werp ook de vraag op

89. Ook de NOvA wijst het experimenteren met uitsluiting van hoger beroep en cassatie (en van het stellen van prejudiciële vragen) af.

90. Reactie NOvA, $\$ 4.6$.

91. Zie voor het eigen perspectief van zo'n deskundig lid M.A. van Hoepen, 'Goede raad...', in: De deskundige in rechte, Nederlandse Vereniging voor Procesrecht, Den Haag: Boom Juridische uitgevers 2007, p. 25 e.v.

92. De lekenrechter wordt aan de unus of aan de meervoudige kamer toegevoegd (art. 4 lid 1 van het consultatievoorstel).

93. Zie ook reacties HR p. 5, RvdR p. 5 en NOvA $\$ 5$ onder 44 . Hoge Raad en Raad voor de rechtspraak vinden dat 'de voor de besluitvorming relevante deskundige inzichten ook aan de orde moeten zijn geweest in het debat tussen partijen'. Of aan dat vereiste is voldaan, is voor partijen gelet op het geheim van de raadkamer echter niet controleerbaar. Bovendien, als de deskundige met een aanvullend inzicht komt in raadkamer, moet de zaak dan weer naar de zitting? Dat is niet werkbaar. 
of deze lekenrechter wel beantwoordt aan artikel $116 \mathrm{Gw}$ : zo'n adviserende rol is toch geen rechtspraak?

Een lekenrechter die alleen adviseert is ook niet nódig. Materieel kan hetzelfde worden bereikt met de inschakeling van een deskundige op de voet van artikel $194 \mathrm{Rv} .{ }^{94}$ Dat kan - anders dan de memorie van toelichting schrijft ${ }^{95}$ - zeer wel zonder tijdrovende complicaties, namelijk door het in artikel 194 lid 2 $\mathrm{Rv}$ voorgeschreven overleg ten overstaan van de regierechter of tijdens de mondelinge behandeling te voeren en de deskundige uit te nodigen voor (de voortzetting van) de mondelinge behandeling. Meer dan een eenvoudig tussenvonnis is daarvoor niet nodig. Dat het in de praktijk vaak anders gaat, rechtvaardigt niet wetswijziging, maar wijziging van die praktijk. Het resultaat is hetzelfde: een deskundig advies aan de rechter. Niet in raadkamer, maar op de zitting en zo hoort het ook.

\section{b) De alternatieve echtscheidingsprocedure}

Ik ben onvoldoende thuis in het familierecht en onthoud mij daarom van uitgebreid commentaar. Ik roep slechts enkele vragen op. Niemand zal bezwaar maken tegen het doel 'de echtscheiding op zo harmonieus mogelijke wijze te laten verlopen', integendeel. De inschakeling van een neutrale gezinsvertegenwoordiger en terugdringen van de papierwinkel zouden daarbij nuttige diensten kunnen bewijzen. Ook een snel beslissende rechter die tijd en aandacht aan de zaak kan besteden en opgeleid en ondersteund is als voorgesteld, zal een belangrijke bijdrage kunnen leveren aan de wenselijke de-escalatie. Maar is daar wetswijziging voor nodig? ${ }^{96}$ Toch alleen als je gezinsvertegenwoordiger en gemeenschappelijk verzoek verplicht stelt? Waar haalt een verplicht opgelegde gezinsvertegenwoordiger zijn handelingsmaatstaf vandaan? Weegt de met zo'n gezinsvertegenwoordiger geboekte winst op tegen het door de verplichtstelling geleden verlies? Kan en mag deze verplichting bij experiment worden opgelegd?

\section{c) Uitbreiding bevoegdheid Ondernemingskamer of pachtkamer}

De memorie van toelichting oppert naast deze drie procedures ook uitbreiding van de zaken die bij bijvoorbeeld de Ondernemingskamer of de pachtkamer kunnen worden aangebracht. ${ }^{97}$ Wat moet ik me bij die uitbreiding voorstellen? Verruiming van het enquêterecht, bijvoorbeeld door toekenning van het enquêterecht aan de ondernemingsraad ${ }^{98}$ of invoering van de

94. Zie over de deskundige als medebeslisser in respectievelijk als adviseur van een rechterlijk college ook voormelde uitgave van de Nederlandse Vereniging voor Procesrecht, G. de Groot, Deskundigen in de rechtspleging: beslissen of adviseren?, p. 9 e.v.

95. MvT, p. 17.

96. Zie voor innovaties in het familierecht die het zonder de experimentenwet kunnen preadvies $\$ 4.13 .1$.

97. MvT, p. 7.

98. Zie bijvoorbeeld J.H.M. Willems in de bundel Geschillen in de vennootschap, serie Van der Heijden Instituut, deel 105, p. 224 e.v., en I. Zaal, De Reikwijdte van medezeggenschap, Monografieën Sociaal recht nr. 63, 2014, \$2.6.7.9. ruziesplitsing in het enquêterecht?99 Dat zou wellicht aardig zijn, maar daarvoor is geen afwijking van het Wetboek van Burgerlijke Rechtsvordering of de Wet RO nodig, maar van het BW. Artikel 66 Wet RO kent geen acties toe, maar bepaalt slechts dat het Amsterdamse Hof voor behandeling van de in die bepaling bedoelde acties een kamer, de Ondernemingskamer, moet vormen. Het zou mij niet verbazen als mutatis mutandis hetzelfde geldt voor uitbreiding van door de pachtkamer behandelde zaken.

\section{Doorgaan met experimenteren, een 'eenzijdig' $96 \mathrm{Rv}$-experiment}

Ik ben het er hartgrondig mee eens dat procedures veel te veel tijd kosten en weinig toegankelijk zijn. Ze moeten inderdaad eenvoudiger, sneller, flexibeler en effectiever worden. En zeker, waar mogelijk ook de-escalerend en conflictoplossend, zoals de Raad voor de rechtspraak toevoegt. ${ }^{100}$ De rechtspraak moet dan ook vooral doorgaan met het verbeteren van de civiele procedure. De invoering van regie- en zaaksrechter onder KEI vormt daartoe een belangrijke stap. ${ }^{101} \mathrm{~W}$ aar nodig en zinvol zijn experimenteren en pilots aangewezen. Het tweede lid van artikel $96 \mathrm{Rv}$ is juist met oog daarop ingevoerd. ${ }^{102}$ Advocaten of andere rechtsbijstandsverleners kunnen ook hun steentje bijdragen.

Een voorbeeld voor een experiment zonder experimentenwet:

- Mak een formulier voor een eenzijdig verzoek op de voet van artikel $96 \mathrm{Rv}$. Zorg ervoor dat het formulier vraagt om alle gegevens die voor een procesinleidend stuk zijn vereist. $^{103}$

- Vermeld daarin voorts het voorstel om de procedure te voeren op de voet van artikel $96 \mathrm{Rv}$. Leg uit dat wat dat betekent en deel mee dat kan worden afgesproken dat het vonnis van de rechter definitief is dan wel dat hoger beroep wordt voorbehouden. ${ }^{104}$ Laat de keus aan de wederpartij (vakje aankruisen) en verklaar dat je als eiser bij voorbaat met die keus instemt.

- Stuur het formulier naar de wederpartij, vraag om een reactie binnen veertien dagen en deel mee dat het formulier bij gebreke daarvan als procesinleiding moet worden beschouwd.

- Vermeld voor vragen en nadere uitleg een adres en telefoonnummer (advocatenkantoor, griffie, juridisch loket).

- Komt er een positieve reactie, dien het formulier in bij de kantonrechter.

99. Zie bijvoorbeeld G. van Solinge en J.H.M. Willems in de zojuist genoemde bundel, p. 109 respectievelijk p. 234.

100. Reactie RvdR, p. 3. De Raad wil deze doelstellingen ook toevoegen aan art. 1 lid 1 en art. 4 lid 1 van het voorstel.

101. Zoals hiervoor in een noot opgemerkt: de digitalisering met het beoogde IT-systeem is gereset. Dat hoeft aan de invoering van zaaks- en regierechter niet in de weg te staan.

102. Per 1 september 2017. Zie memorie van toelichting KEI I, Kamerstukken II 2014/15, 34059, 3, p. 4 en 84.

103. Art. 30a Rv (KEI). Ook een kort briefje dat niet aan die eisen voldoet, werkt voor art. 96 Rv. Dit kan dan echter niet zonder aanvulling als procesinleiding gelden.

104. Zonder voorbehoud staat appèl niet open, art. 333 Rv. 
- Komt er een negatieve reactie, volg dan de weg van de gewone procesinleiding.

Alles graag in begrijpelijk Nederlands.

Dit kan nu alleen nog bij de Rechtbanken Midden-Nederland en Gelderland, die dankzij de invoering van KEI aldaar de informele procesinleiding kennen. Voor de rest van het land kan een formulier worden opgesteld dat bij negatieve reactie als dagvaarding dient. Vele varianten zijn denkbaar, bijvoorbeeld toegespitst op de MKB-rechter, de Spreekuurrechter, de Burenrechter of andere vormen van rechtspraak op locatie, zoals de buurtrechter ${ }^{105}$. Voor elke variant valt een format te bedenken. Welke advocaat of rechtsbijstandverlener zet zo'n formulier op zijn website?

De memorie van toelichting wijst erop, we zagen dat al, dat partijen door verslechterde verhoudingen vaak geen zin hebben in de artikel $96 \mathrm{Rv}$-weg. ${ }^{106}$ Volgens HiiL is dan ook 'de gedachte dat partijen gezamenlijk zouden kiezen voor nieuwe procedures (...) terecht verlaten'. ${ }^{107}$ Dat is mijns inziens te snel opgegeven. Dat laat ook het project Spreekuurrechter zien. ${ }^{108}$ Met wat inventiviteit en creativiteit kan de instemming van de verweerder nog best een handje geholpen worden. Laat de rechtspraak - bij voorkeur in overleg met de Orde van Advocaten en andere betrokkenen - het voortouw nemen en formats en formulieren als door mij geschetst voor verschillende soorten procedures ontwikkelen. Die - landelijk herkenbare formats houden natuurlijk rekening met de belangen van beide partijen. Vul dit aan met enige propaganda, goede voorlichting en heldere keuzepagina's op de website van de rechtspraak en klaar zijn we. De eiser vindt er het gewenste formulier en voor de verweerder is acceptatie aantrekkelijk indien hij ziet dat er wat te kiezen valt en ook met zijn belangen rekening is gehouden. Doordat het formulier subsidiair ook procesinleiding is, weet de verweerder dat vluchten niet meer kan: de zaak komt hoe dan ook voor de rechter. Beide partijen winnen tempo. Desgewenst besparen ze kosten door geen advocaat in de arm te nemen. ${ }^{109}$

Moet dat in de vorm van een experiment of starten we gewoon? Het kan allebei. Bijstelling van tijd tot tijd blijft mogelijk. En het kan zeker zonder experimentenwet.

\section{Het geld}

Een enkele opmerking over het geld. Verbeteringen van de rechtspraak kunnen leiden tot meer maar ook tot minder kosten. Ik vrees dat het meestal het eerste zal zijn. Regie- en maatwerk, $96 \mathrm{Rv}$-achtige procedures, de procedures in de voorbeelden van de memorie van toelichting, zij zullen alle meer tijd en

105. Zie het regeerakkoord van 10 oktober 2017 , t.a.p. p. 7 .

106. Opmerkelijk: volgens Lennaerts weigerden alle 'overheden/instanties' medewerking aan het project. Zie A.H.J. Lennaerts, 'De proef (met een) Spreekuurrechter', NJB 2017, p. 2943.

107. Reactie HiiL onder 'Sterke punten'.

108. Zie Lennaerts 2017, t.a.p. p. 2937 ev.

109. Zoals gezegd: zolang maar geen afbreuk wordt gedaan aan hun recht op rechtsbijstand. aandacht van de rechter vragen en dus meer geld kosten. Bovendien, als procedures inderdaad eenvoudiger, sneller, flexibeler en effectiever worden, worden ze aantrekkelijker - dat is toch de bedoeling? - en krijgt de rechtspraak meer te doen. ${ }^{110}$ Dat vergt een hoger budget. Ik ben niet erg optimistisch dat dat er komt. Veel ideeën rond experimenten willen de rechter dichter bij de burger brengen. De burger wil de rechter zelf spreken. ${ }^{111}$ Het streven is de afgelopen jaren echter tegengesteld geweest. De herziening van de gerechtelijke kaart was wat dat betreft effectief: deze herziening had volgens de NVvR minder zaken, minder zittingen, en geringere zichtbaarheid tot gevolg. ${ }^{112}$ Tussen 2009 en 2012 stegen de griffierechten met $43 \%$. Als gevolg daarvan verminderde de instroom van zaken met $20 \%{ }^{113}$ De koers lijkt veeleer te zijn: kosten verminderen en de burger bij de rechter weg houden. In dat licht moet ook de opmerking in de memorie van toelichting dat het consultatiewetsvoorstel geen financiële gevolgen heeft, ${ }^{114}$ worden geplaatst. Het probleem is niet een gebrek aan aandacht voor kortere doorloopsnelheid maar een gebrek aan investering.

Ook de Hoge Raad, de Raad voor de rechtspraak en de NOvA vragen aandacht voor de kosten, maar zij hebben vooral het oog op de kosten van de experimenten. ${ }^{115}$ Natuurlijk moet er bij het project Spreekuurrechter voorzien zijn in de kosten van Ton Lennaerts c.s. Maar ik maak mij meer zorgen over het tijdig incalculeren van de kosten gemoeid met de aanstelling van al die andere bij geslaagd experiment in de rest van het land benodigde Ton Lennaertsen. ${ }^{116}$

Degene die het meent met experimenten wekt verwachtingen en moet inderdaad rekening houden met het risico dat het experiment slaagt. Indien dan verhoging van kosten inderdaad is te verwachten, moet hij daartoe bij voorbaat bereid zijn. ${ }^{117}$ Het niet invoeren van een succesvol beproefde innovatieve procedure of het wel invoeren vergezeld van nieuwe wachtlijsten heeft geen zin.

Ik ben ervan overtuigd dat het mogelijk is civiele procedures eenvoudiger, sneller, flexibeler en effectiever te maken. Het kost wel geld. Is dat er niet, dan gaat het - weer - niet lukken.

\footnotetext{
110. Zo ook reactie HiiL, $\$ 3$.

111. Zie Lennaerts 2017, t.a.p. p. 2938.

112. https://nvvr.org/uploads/documenten/De-HGK-in-de-praktijkervaringen-van-NVvR-leden.pdf.

113. Evaluatie Wet griffierechten burgerlijke zaken, p. 7, zie www. rechtspraak.nl/SiteCollectionDocuments/Evaluatie-Wet-griffierechtenburgerlijke-zaken-Cahier-2017-9.pdf.

114. MvT, p. 20.

115. Zie hun reacties op respectievelijk p. 7 en p. 8.

116. Zie ook reactie HiiL, p. 4.

117. Zie ook preadvies $₫ 4.1,4.4$ en 5.4 .5 .
} 


\section{Conclusies}

Tal van vragen heb ik niet kunnen bespreken. ${ }^{118}$ Maar het is tijd voor conclusies. Het consultatievoorstel geeft de AMvBregelgever - afgezien van de fundamentele beginselen van procesrecht - voor onbepaalde tijd een vrijwel ongeclausuleerde bevoegdheid de geldende regels van het procesrecht opzij te zetten. Het is de vraag of dat strookt met (de strekking van) de Grondwet en past binnen de staatrechtelijke verhoudingen. De bevoegdheid is hoe dan ook te ruim doordat het experimenten mogelijk maakt en ook daadwerkelijk beoogt die de verwezenlijking van burgerlijke rechten en verplichtingen - tegen de wil van (een van) partijen - kan aantasten. Nadere reflectie is gewenst.

De rechtspraak zelf heeft ruimte genoeg om te experimenteren. Waar dwingende bepalingen daaraan in de weg staan en men een keuze voor vernieuwing niet zonder experiment aandurft, is afzonderlijke daarop gerichte wetgeving mogelijk. Wil men toch een raamwet, dan moeten de bepalingen van de experimenteerbare wetten stuk voor stuk worden nagelopen op experimentabiliteit en criteria worden ontwikkeld die toelaatbare experimenten onderscheidt van niet toelaatbare.

Kortom, de wetgever moet zich driemaal bedenken voordat hij een dergelijke twijfelachtige en grotendeels onnodige carte blanche in handen van de AMvB-regelgever speelt.

Ondertussen moet de rechtspraak er zeker naar streven de procedures ten behoeve van burgers en bedrijven eenvoudiger, sneller, flexibeler en effectiever te maken, waar nodig en aanvaardbaar met experimenten. Nog lang niet alle inventiviteit en creativiteit is uitgeput. Probeer eens het 'eenzijdig' 96 Rvexperiment. $\mathrm{Al}$ die experimenten hebben echter alleen zin, indien de financiële middelen worden verschaft om de consequenties te trekken uit een geslaagd experiment!

118. Bijvoorbeeld de overgangsproblematiek: welke regels zijn van toepassing op lopende procedures indien de termijn voor een experiment, maximaal drie jaar, verstreken is? Herleven dan de gewone regels? De NOvA wijst er terecht op dat het consultatievoorstel 'geen enkele vorm van overgangsrecht bevat' (reactie p. 3). Ook de Hoge Raad en de Raad voor de rechtspraak maken er een opmerking over (reacties HR p. 5 en RvdR $\S 8)$. Interessant is ook de vraag of er een sanctie is op schending van art. 1 lid 2 van het wetsvoorstel. Staat bestuursrechtelijk bezwaar en beroep open, indien een experiment bijvoorbeeld de toegang tot de rechter beperkt? 